\title{
Credit Risk Management and Financial Performance of Listed Banks in Ghana
}

\author{
Jacob Akomeah* ${ }^{*} \quad$ Raymond Agumeh Siaw Frimpong \\ School of Business, University of Cape Coast, Cape Coast, Ghana
}

\begin{abstract}
The purpose of this study was to examine the effect of credit risk management on the performance of selected listed commercial banks in Ghana. The study used secondary data collected from seven (7) banks listed on the Ghana Stock Exchange for a period of ten (10) years covering 2007-2016 with a total of seventy (70) observations. The credit risk management variables (independent variables) used were non-performing loans, loan loss provision, capital adequacy, with bank size (as controlling variable) whiles the financial performance of commercial banks (as dependent variable) was measured using return on asset. The data was examined using standard descriptive statistics and fixed effect model for hypothesis testing. Based on the test conducted on the data collected and the analyses of the results, this study found a significant relationship between the credit risk management variables (NPL, CAR and SIZE) and the profitability of listed banks in Ghana. In general, banks need to maintain an optimum level of CAR as per regulatory requirement so that they will not have difficulty in meeting their financial obligations, be able to absorb any financial shocks that may arise, protect their depositors' investment and thus promotes the stability of the financial system. The study further recommends for banks in Ghana to control and monitor NPL, and keep the level of NPL as low as possible by emphasizing more on the ability of customers to pay back before credit approvals are given, a practice that will enable banks to achieve higher performance.
\end{abstract}

Keywords: Non- Performing Loans, Loan Loss Provision, Capital Adequacy Ratio, Return on Assets, Ghana Stock Exchange, Fixed Effect, Random Effect.

DOI: $10.7176 /$ RJFA/11-6-05

Publication date:March $31^{\text {st }} 2020$

\section{Introduction}

The role of banks remains central in financing economic activities and its effectiveness could exert positive impact on the overall economy. A sound and profitable banking sector is better able to withstand negative shocks and contribute to the stability of the financial system (Athanasoglou, Brissimis \& Delis, 2008). Banks play a major role in all the economic and financial activities in modern society. One of the core activities of the banking industry both internationally and locally is the creation of credit to deserving and deficit units of the economy (Bessis, 2010). Generally, credit creation is the main income generating activity of the financial institutions. But these activities involve huge risks to both the lender and the borrower. When financial institutions issue loans, there is a risk of borrower default. When banks collect deposits and lend them to other clients, they put clients' savings at risk. The default of small number of borrowers may result to large losses for a financial institution which can lead to massive financial distress affecting the whole economy (Bessis, 2010). On the other hand, a bank with high credit risk has high bankruptcy risk that puts the depositors' money in jeopardy. In a bid to survive and maintain adequate profit level in this highly competitive environment, banks tend to take excessive risks, thus exposing the bank to credit risk. The higher the banks' exposure to credit risk, the higher the tendency of the banks to experience financial crisis and vice-versa.

Credit Risk is the potential that credit borrower/counter party fails to meet the obligations on agreed terms. There is a tendency for the borrower to default from his commitments for one or other reasons resulting in crystallization of credit risk by the financial institution. These losses could take the form of outright default or alternatively, losses from changes in portfolio value arising from actual or perceived deterioration in credit quality. Credit risk is the uncertainty associated with borrowers' loan repayments. In general when borrowers' asset values exceed their indebtedness they repay loans but when borrowers' assets values are less than loan values, they do not repay and they could therefore exercise their option to default. Credit risk management is necessary to minimize the risk and maximize financial institution's risk adjusted rate of return by assuming and maintaining credit exposure within the acceptable parameters (Pandey, 2008).

Credit risk is the most significant risk faced by banks and the success of the financial institutions depends on the accurate measurement and efficient management of this risk to a greater extent than any other risk (Giesecke, 2004). Increases in credit risk will raise the marginal cost of debt and equity, which in turn increases the cost of funds for the Bank (Basel Committee, 1999). The Basel Committee on Banking Supervision (2001) also defined it as the possibility of losing the outstanding loan partially or totally, due to credit events (default risk). It is true that, the credit function of Banks enhance the ability of investors to exploit desired profitable ventures. The Basel Committee on Banking Supervision (1999) asserts that loans are the largest and most obvious source of credit risk.

Profitability of Banks is greatly affected by the bank's credit risk since a huge amount of banks revenue is 
from the loans given out on which interest is derived. Nonetheless, the performance of the banks is highly threatened by credit risk. As such, credit risk needs to be properly managed (Bhattarai, 2016).

The financial sector, especially commercial banks, has been faced with serious financial challenges since 2015. As a result, some of these commercial banks have wound up leaving customers to their fate. Others have been consolidated, taken over and merged up, which has resulted in loss of jobs and laying off thousands of employees of such affected banks. It is important to note that the major cause of the winding up of these banks is as a result of poor management of their finance and credit. Many of them were writing off huge amounts of debt yearly and also reflected some going concern issues that related to their management of credit and finance. The reasons for the failure of these banks have sparked the interest of the researcher in conducting further studies into the management of finance and credit in Ghanaian listed banks. It is intriguing to note that few research works have been conducted on the effect of credit risk management on banks' performance in the Ghanaian context. These few known research include Afriyie and Akotey (2012), Annor and Obeng (2017), Boahene, Dasah and Agyei (2012). The five to seven years period data used by these researchers have provided a gap for this study to fill by extending the period from five years to ten years as this can affirm or contradict their findings. It is in the light of the above, that this study seeks to empirically examine the effects of credit risk management on the financial performance of some selected commercial banks in Ghana for the period 2007 to 2016. The focus of this study would be to assess the extent to which banks manage their credit risk, the measures put in place to manage the increasing rate of default, whether banks have met the regulatory capital requirement with respect to their risk profiles based on the new Basel Accord adopted by Ghana, to improve buffer for risk absorption in the industry. Ultimately, the study would find out the extent to which banks' financial performance are affected by high rate of default using Return on Assets, Non-performing Loans, Loan Loss Provision, and Capital Adequacy Ratio as measures for profitability.

Specifically, the study would seek to establish the relationship between profitability of Ghanaian commercial banks and Non-Performing Loans, Loans Loss Provisions, and Capital Adequacy Ratio. The study was guided by the following research hypotheses:

$\mathrm{H}_{01}$ : There is no significant effect of Non- Performing Loans on banks' profitability in Ghana. $\mathrm{H}_{02}$ : There is no significant effect of Loan Loss Provisions on profitability of banks in Ghana. $\mathrm{H}_{03}$ : Capital Adequacy Ratio has no significant effect on the profitability of banks in Ghana.

$\mathrm{H}_{04}$ : There is no significant effect of Bank Size on profitability (ROA).

\section{Literature review}

\subsection{Return on Asset (ROA) -Profitability Indicator}

Return on Assets is the measure of efficiency which determines how well the banks use its scarce resources to generate profits. It is the ratio of net income to the total asset. A higher ratio is an indication of a better financial performance. This ratio has been used in similar studies by Athanasoglou, Brissimis and Delis (2008); Perera, Skully and Chaudhry (2013).

\subsection{Capital Adequacy Ratio (CAR) and Bank Profitability}

Capital Adequacy is very essential for the solvency and profitability of banks. This is because the business of banking is risky due to the possibility that loans may not be paid back leading to financial losses to the bank. Banks are therefore required to have adequate capital, not only to remain solvent, but also to avoid the failure of the financial system. Theoretically, banks with good capital adequacy ratio have good profitability because they are able to withstand negative shocks. A bank with a strong capital adequacy is able to absorb possible loan losses, which further reduces loan loss provisions in the income statement, increasing profitability and thus avoids bank insolvency and failure. Thus, it is imperative that banks increase their capital base to be able to do larger transactions and have a more stable banking sector. The Bank of Ghana (BOG) requires Commercial Banks to maintain a $10 \%$ minimum capital adequacy ratio.

\subsection{Loan Loss Provision (LLP) and Bank Profitability}

Loan Loss Provision (LLP) is a non-cash expense for banks to account for future losses on loan defaults. Banks do operate on the assumption that a certain percentage of loans will be defaulted or become slow paying. As a result, banks enter a percentage as an expense when calculating their pre-tax incomes. This guarantees a bank's solvency and capitalization if the default occurs. The loan loss provision allocated each year increases with the riskiness of the loans a given bank makes. A bank making a small number of risky loans will have a low loan loss provision compared to a bank taking higher risks. Loan loss provision of the banks is of paramount importance in affecting its profitability. Well-managed banks are perceived to have lower loan loss provision and such advantage translates into higher profitability (Comptroller's handbook). The management of credit risk in the banking industry follows the progress of risk identification; assessment and measurement, monitoring and control. It involves identification of potential risk factor, estimation of their consequences and impact, monitoring activities 
exposed to the identified risk factors and put in place control measures to prevent or reduce the undesirable effects. This process applies within the policies, strategies and operational framework of the bank. An effective system that ensures repayment of loans by borrowers is critical in dealing with asymmetric information problems and in reducing the level of loan losses, thus the long-term success of any banking organization (Basel Committee, 1999).

\subsection{Non-Performing Loans (NPLs) and Bank Profitability}

The International Monetary Fund (IMF) defines a non-performing loan as any loan in which interest and principal payments are more than 90 days overdue; or more than 90 days' worth of interest has been refinanced, capitalized, or delayed by agreement; or payments are less than 90 days overdue but are no longer anticipated (International Monetary Fund, 2019). Again, a non-performing loan is one in which the maturity date has passed but at least part of the loan is still outstanding. The specific definition is dependent upon the loan's particular terms. The huge bad debts recorded by most Ghanaian banks in 2009 and early parts of 2010 have affected the performance of the financial intermediaries.

Non-performing loans are used to measure the positive and fitness of a bank's credit risk management. Nonperforming loans have a fundamental effect on how banks set rates, and the problem has been the fact that those who pay their loans then have to pay for those who do not. Healthy and sustainable profitability is essential and very vital in maintaining the stability of the banking system. Even if solvency is high, poor profitability weakens the capacity of a bank to absorb negative shocks, which will eventually affect solvency, hence the urgent need to reduce credit risk and its associated phenomenon of non-performing loans.

\subsection{Empirical Review}

Kargi (2011) estimated the effect of credit risk on the profitability of Nigerian banks. Data on credit risk and profitability ratios were collected from 2004 to 2008. The analysis of this data involved descriptive, correlation and regression techniques. The result was that credit risk management has a substantial influence on the profitability of Nigerian banks. Other findings on the study showed that a rise in nonperforming loans negatively affect profitability and liquidity.

Gizaw, Kebede and Selvara (2013) examined the impact of credit risk on the profitability of commercial banks in Ethiopia. Secondary data was retrieved from 8 sample commercial banks for a period of 12 years from annual reports of these banks. They found that credit risk determinants nonperforming loans, loan loss provisions and capital adequacy had a significant impact on the profitability of commercial banks in Ethiopia. Therefore the researchers stressed on the need to strengthen the credit risk management policies to gain better financial standing for commercial banks in commercial in Ethiopia.

A study by Serwadda (2018) analysed the impact of credit risk management on the financial performance of commercial banks in Uganda. The study concluded that credit risk management factors as analysed were crucial factors in determining the profitability of Ugandan commercial banks and hence banks should pay more attention to them. For instance, these results showed that banks' performance was inversely influenced by non-performing loans which may expose them to large magnitudes of illiquidity and financial crisis. Hence, the study recommended that Ugandan banks should design effective strategies to deal with credit risk management issues accordingly. This is because poor credit risk management policies affect banks' performance adversely as they impact on asset quality which eventually results in increased loan losses plus non-performing loans thereby exposing banks to financial distress. Banks should create efficient management systems by working under good credit environment with strong loan evaluations, loan granting processes, establishing efficient credit administration control systems for constant monitoring and flow of the entire loan processes right from credit applications to disbursements and throughout the whole repayment cycles or loan tenures to be able to compete favorably.

Alshatti (2015) examined the effect of the credit risk management on the financial performance (profitability) of the Jordanian commercial banks. The researcher concluded that the credit risk management indicators considered in the study were important variables in explaining profitability of Jordanian commercial banks. Employing non-performing loans which banks normally set aside money to cover potential losses (loan loss provisions) and write off bad debts in the profit and loss account are indicators of credit risk management. In spite of a large number of unpaid loans, NPL ratio had a positive effect on profitability. Therefore, credit interest/credit facilities did not affect the profits of the banks instead to focus more on the factors rather than these variables. Banks should take into consideration, the indicators of non-performing loans/Gross loans, Provision for facilities loss/Net facilities and the leverage ratio that were found significant in determining credit risk management.

$\mathrm{Li}$ and Zou (2014) conducted a study whose main objective was to determine the relationship between credit risk management and profitability of commercial banks in Europe and ascertain whether the relationship is stable or fluctuating. The study obtained annual and risk reports for 47 largest commercial banks in Europe between the period of 2007 and 2012 from which they obtained information on return on assets (ROA), return on equity (ROE) which were used as proxies of profitability while non-performing loan ratio (NPLR) and capital adequacy ratio 
(CAR) were proxies of credit risk management. The research findings established that credit risk management did not have a positive effect on commercial banks' profitability. The study revealed that NPLR had a significant relationship on both ROA and ROE while CAR had an insignificant relationship on both ROA and ROE. The researchers further established that there was a fluctuating relationship between profit and credit risk management during the period investigated. They recommended that managers ought to put more effort on credit risk management specifically to control non-performing loans.

Aboagye and Otieku, (2010) conducted a study on credit risk management and profitability of financial institutions in Ghana (Sweden). The main objective was to find out if management of credit risk had a significant impact on profitability of financial institutions. They found out that credit risk management in financial institutions has become more important not only because of the financial crisis that the world is experiencing nowadays but also the introduction of Basel II. They concluded that since granting credit is one of the main sources of income in financial institutions, the management of credit risk affects the profitability of the financial institutions.

Juliana (2017) conducted a study on the impact of Credit Risk on the Financial Performance of Chinese Banks. The results revealed that credit risk management improved over the past years as prudential techniques were put in place to reduce the negative impact of credit risk on the financial performance of banks. The study observed that non-performing loans and capital adequacy as measures of credit risk to had significant impact on financial performance. Hence managers should pay more attention to improving capital adequacy since it positively enhances financial performance while reducing non-performing loans by applying modern strategies and techniques for credit risk management.

The study of Boahene, Dasah and Agyei (2012) utilized the regression analysis to reveal the connection between credit risk and profitability of selected banks. They established that credit risk components (nonperforming loan rate, net charge-off rate, and the pre-provision profit as a percentage of net total loans and advances) have a positive and significant relationship with bank profitability. This shows that banks in Ghana enjoy high profitability regardless of high credit risk, an opposing view to other views expressed in many studies that credit risk indicators are negatively related to profitability.

\subsection{Conceptual Framework}

A conceptual framework is a scheme of concepts or variables which the researcher would operationalize in order to achieve set objectives. It is a pictorial demonstration of the theory portrayed as a model where researcher shows the link between variables in order to reveal the relationship between the independent, dependent and control variables.

Figure 1: Conceptual Framework

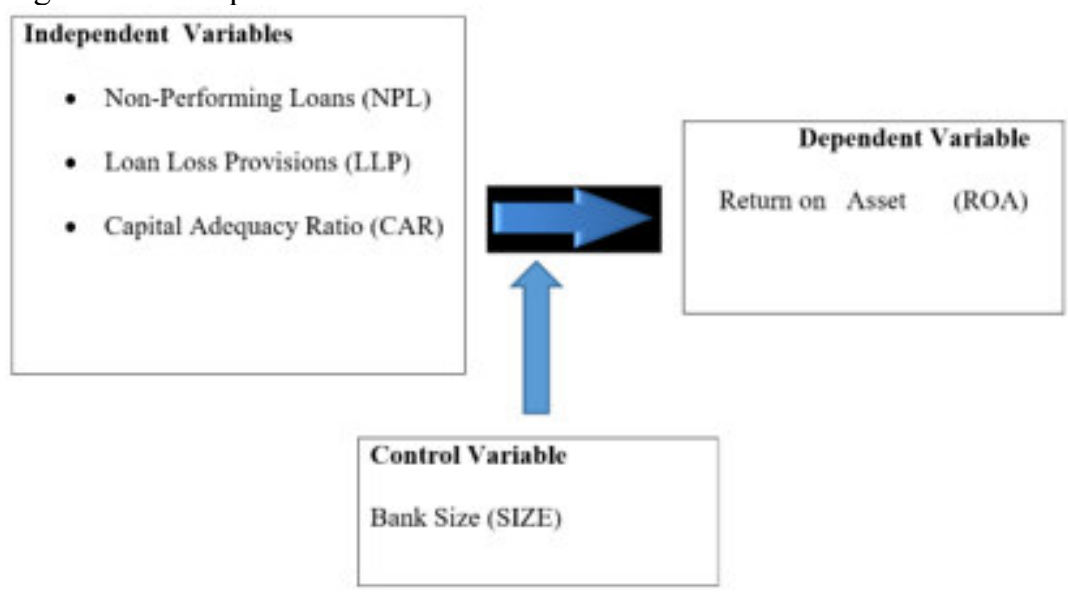

Source: Researchers' own Conceptualization

\section{Methodology}

\subsection{Research Design and data collection}

The researcher used quantitative approach to investigate the effect of credit risk management on the profitability of commercial banks using a panel data. The study covered the period 2007 to 2016 . The study employed secondary data. Audited financial statements of seven (7) selected banks were retrieved from the Ghana Stock Exchange (GSE) website. Where the financial statements of a particular period for a selected bank were not available at the Ghana Stock Exchange (GSE) website, they were retrieved from the websites of that particular bank. The data was used in computing Non-performing loans (NPL), Loan loss provisions (LLP), Capital adequacy ratio (CAR), and other variables. 


\subsection{Target Population}

The target population for this research was commercial banks operating in Ghana and have been operational for the period 2007-2016. Commercial banks are considered to be a fair representation of banks because they constitute the largest market share of the financial institutions in terms of assets and liabilities. The target population for the study consists of all nine (9) listed commercial banks on the GSE.

\subsection{Sampling Technique and Sample Size}

There are currently nine (9) commercial banks listed on the Ghana Stock Exchange. Out of these nine (9) commercial banks listed, seven (7) banks, namely Standard Chartered Bank (Ghana) Limited, Ghana Commercial Bank, Ecobank (Ghana) Limited, Access Bank (Ghana), HCF Bank (Ghana), Societe Generale (Ghana) Limited, and $\mathrm{Cal}$ Bank Limited were selected as the sample size for the study.

\subsection{Data Processing and Analysis}

The data collected was analyzed statistically and quantitatively by the use of measures of central tendency, namely: mean, median, maximum, minimum and standard deviation. The variables were verified for stationarity by subjecting them to panel unit root test. In this study, relevant tests were carried out alongside other regression models (Fixed Effects and Random Effects models), to confirm the reliability or otherwise of the OLS in this study. Hausman test was carried out to determine which of the regression models (Fixed Effects and Random Effects) was appropriate. Multicollinearity test was carried out to observe whether the explanatory variables were highly correlated or not. The data was subjected to computerized analysis using E- Views version 9.

\subsection{Dependent variable: Profitability}

The most common measure of bank performance is profitability. Profitability is measured by using Return on Assets (ROA), Return on Equity (ROE) and Cost of Income Ratio (Hosna, Manzura, and Juanjuan, 2009). The study however focuses on Return on Assets (ROA) as the dependent variable. Return on Assets (ROA), which is, Net Profit (Income) /Total Assets, measures the ability of management to acquire deposits at a reasonable cost and invest them in profitable investments (Hosna, Manzura, and Juanjuan, 2009). While it is expected that banks would bear some bad loans and losses in their lending activities, the objective of the bank is to minimize such losses in order to enhance its profitability.

\subsection{Independent Variables}

The independent variables used in the study in estimating the regression model for the effect of credit risk management on banks' profitability are: Non-Performing Loans Ratio (NPL), Loan Loss Provision Ratio (LLP), Capital Adequacy Ratio (CAR) and Bank size (SIZE)

\subsubsection{Non- Performing Loans (NPL)}

This is an independent variable and is chosen because it is an indicator of credit risk management. Non-performing loan indicates how banks manage their credit risk because it defines the proportion of loan losses amount in relation to Total Loan amount (Hosna, Manzura, \& Juanjuan, 2009). The level of non-performing loans is of serious concern to bank regulators/supervisors due to its role in the failure of several diversified and non-diversified financial institutions, both in developed and developing countries, especially Ghana. Earlier studies have showed that non-performing loans negatively affect efficiency and return on assets (Tetteh, 2012; Boahene et al., 2012).The researcher expects non-performing loans to have an adverse relationship with banks' financial performance.

A loan is normally defined as non-performing when customer's payments are in arrears (Kauko, 2012, p.196).

Generally, default can be defined in the following ways: Non-payment of interest 90 days after the interest due date; Non-payment of a loan 90 days after the loan maturity date; Restructuring of the borrower's loans; and Filing for bankruptcy, the appointment of administrators and liquidation.

\subsubsection{Loan Loss Provision (LLP)}

This is also an independent variable and chosen because as banks make loans, they need to make provisions for loan losses in their books. The higher this provision becomes, relative to the size of total loans, the riskier the banks' become. The immediate consequences of non-performing loans is reduction in banks profitability, and this arises from disposal costs like provisions for credit losses (LLP), and direct write offs for bad debt, hence the inclusion of this variable. Ahmed, Takeda, and Shawn (1998) assert that loan loss provision has a significant positive influence on non-performing loans. Therefore, an increase in loan loss provision indicates an increase in credit risk and deterioration in the quality of loans consequently affecting bank performance adversely. An increase in the value of the provision for losses relative to total loan is an indication that the bank's assets are becoming more difficult to collect. This is LLP/TLA and expects to have an inverse relationship with ROA.

\subsubsection{Capital Adequacy Ratio (CAR)}

This was used as an independent variable because the core measure of a bank's financial strength in the face of its risk profile, particularly credit risk from a regulator's point of view. It consists of financial capital most reliable, 
liquid and primarily shareholders' equity required for credit risk and total risk management and/ or absorption (BoG, 2008). The results from earlier studies showed that performance improvements follow regulatory changes and that risk explains differences in banks while the capital adequacy ratio has a positive impact on the net interest margin, which result in higher profitability (Epure, 2012). Banks with good Capital Adequacy Ratio have good profitability. With good capital requirement, banks are able to absorb loans that have gone bad through provisions for credit losses and outright write-offs, and are able to take advantage of the numerous opportunities within the banking industry, hence its inclusion in the model. CAR is regulatory capital requirement, computed as shareholders' fund divided by total asset (Total Capital/TA).This is expected to have a positive relationship with profitability.

\subsection{Control variable:}

\subsubsection{Bank Size}

It is obvious that banks' size affects profitability. This control variable is operationalized in two ways in the literature of credit risk management. The first type uses the natural logarithm of assets to determine the size of a bank. This is used in the studies of Samiloglu and Demirgunes (2008) and Sharma and Kumar (2011). But the most widely used type of measurement is the natural logarithm of revenue, which was used by Padachi (2010), Dong and Su (2010), Deloof (2003), Raheman and Nasr (2007) and Karaduman (2011). To enhance robustness of the study, this control variable was used in the analysis. Size was measured as Natural Logarithm of Net Revenue.

\subsection{Model Specification}

The model used Return on Assets (ROA) as dependent variable and three independent variables, which include Non-Performing Loans (NPL), Loan Loss Provision (LLP), and Capital Adequacy Ratio (CAR) with Bank Size (SIZE) as a control variable.

Generally, this model is specified as:

Qit $=\alpha+$ Xit $\beta+$ eit

Where,

Qit $=$ Profitability $(\mathrm{ROA})$

$\alpha=$ the intercept

$\beta=$ coefficient of independent variables

$\mathrm{Xit}=$ independent variables of bank $\mathrm{i}$ at time $\mathrm{t}$

$\varepsilon i t=$ error term of bank $\mathrm{i}$ at time $\mathrm{t}$

Specifically, the relationship between credit risk management and profitability of listed commercial banks in Ghana was modeled using the Ordinary Least Square (OLS) regression technique.

$\mathrm{ROA}_{\text {it }}=\beta_{0}+\beta_{1} \mathrm{NPL}_{\mathrm{it}}+\beta_{2} \mathrm{LLP}_{\mathrm{it}}+\beta_{3} \mathrm{CAR}_{\mathrm{it}}+\beta_{4} \mathrm{SIZEit}+\varepsilon \mathrm{it}$

Where:

$\mathrm{ROA}_{i \mathrm{i}}=$ Return on Assets of bank $\mathrm{i}$ in year $\mathrm{t}$.

$\mathrm{NPL}_{\mathrm{it}}=$ Non-Performing Loans of bank $\mathrm{i}$ in year $\mathrm{t}$

$\mathrm{LLP}_{\text {it }}=$ Loan Loss Provision of bank $\mathrm{i}$ in year $\mathrm{t}$

$\mathrm{CAR}_{\mathrm{it}}=$ Capital Adequacy Ratio of bank $\mathrm{i}$ in year $\mathrm{t}$

SIZE it= Size of bank $i$ in year $t$

$\varepsilon i t=$ Error term of bank $\mathrm{i}$ in year $\mathrm{t}$

$\beta_{0}=$ the intercept

$\beta_{1}-\beta_{3}=$ Coefficients of Independent Variables

$\beta_{4}=$ Coefficients of Control Variables.

Table 1: Variables Measurement

\begin{tabular}{|l|l|l|}
\hline & Variable Name & Calculating Method \\
\hline Dependent Variable & ROA & Net income/ Total Assets \\
\hline Independent Variables & NPL & NPL/ Total Loans \& Advances \\
& LLP & LLP/ Total Loans \& Advances \\
& CAR & Total Capital/ Total Assets \\
\hline Control Variable & Bank Size (SIZE) & Natural logarithm of total assets of banks. \\
\hline
\end{tabular}

Source: Developed by the Researchers based on literature

\section{Results and discussion \\ 4.1 Stationarity Tests \\ Panel unit root test}

The variables were verified for stationarity by subjecting them to panel unit root test using Levin, Lin \& Chu, Im, Pesaran and Shin W-stat, ADF - Fisher Chi-square and PP - Fisher Chi-square test for stationary test. All variables used in the study namely: Return on Asset (ROA), Non-Performing Loans (NPL), Loan Loss Provision (LLP), 
Capital Adequacy Ratio (CAR) and Bank Size (SIZE) were stationary at levels. For a variable to be accepted as stationary, it was expected to have more than $50 \%$ of the methods (Levin, Lin \& Chu, Im Pesaran and Shin Wstat, ADF-Fisher Chi-square and PP-Fisher Chi-square) confirming its stationarity.

Table 2- Results of the Panel Unit Root test for the Dependent, Independent and Control Variables

\begin{tabular}{llllll}
\hline \multirow{2}{*}{ Method } & \multicolumn{5}{c}{ Probability } \\
\cline { 2 - 6 } & ROA & NPL & LLP & CAR & SIZE \\
\hline Levin, Lin \& Chu t* & 0.0000 & 0.0452 & 0.0000 & 0.0000 & 0.0000 \\
Im, Pesaran and Shin W-stat & 0.0000 & 0.1019 & 0.0033 & 0.0033 & 0.0000 \\
ADF - Fisher Chi-square & 0.0001 & 0.0166 & 0.0027 & 0.0027 & 0.0000 \\
PP - Fisher Chi-square & 0.0000 & 0.0166 & 0.0000 & 0.0000 & 0.0001 \\
\hline
\end{tabular}

Source: Computed by researchers from annual reports of listed Banks (2007-2016

All the four methods in Table 2, suggest that ROA, LLP, CAR and SIZE were stationary at levels. This represents $100 \%$. Only NPL has three of the methods, representing $75 \%$ confirming its stationarity at levels.

\subsection{Descriptive Statistics}

Table 3 presents the descriptive statistics of the variables used in the study. The results showed that on average, the banks made profit of $3.94 \%$ as measured by return on asset (ROA). This means that during the period 20072016 , the total assets of commercial banks listed on GSE generated 3.94\% return which is not a good indicator of financial performance. The minimum capital adequacy ratio is $7.24 \%$ which is lower than the regulatory requirement of $10 \%$, suggesting that there are some commercial banks which are non-compliance. However, the average CAR is $14.21 \%$, which is greater than the Bank of Ghana regulatory requirement. The Non-performing loan has a maximum value of $33 \%$ to minimum of $1 \%$ with the mean and standard deviation of 9.39 and 8.38 respectively which indicates that the ability of banks to manage credit risk is very low. The loan loss provision has a minimum of $1 \%$ and a maximum of $15.6 \%$ with a standard deviation of 3.72 .

Table 3- Descriptive Statistics of the Dependent, Independent, and Control Variables

\begin{tabular}{lccccc}
\hline & ROA & NPL & LLP & CAR & SIZE \\
\hline Mean & 3.944200 & 9.390800 & 4.994800 & 14.21160 & 8.278200 \\
Median & 3.910000 & 6.100000 & 3.620000 & 14.75000 & 8.320000 \\
Maximum & 12.80000 & 33.00000 & 15.60000 & 33.38000 & 9.080000 \\
Minimum & -0.530000 & 1.000000 & 1.000000 & 7.240000 & 7.100000 \\
Std. Dev. & 2.273647 & 8.379366 & 3.717510 & 4.546205 & 0.453749 \\
Skewness & 1.089403 & 1.274739 & 1.292100 & 1.443331 & -0.682916 \\
Kurtosis & 5.946791 & 3.797123 & 3.828015 & 7.394945 & 3.212997 \\
Probability & 0.000001 & 0.000592 & 0.000466 & 0.000000 & 0.136629 \\
\hline
\end{tabular}

Source: Computed by researchers from annual reports of listed Banks (2007-2016)

\subsection{Fixed-Effects and Random-Effects Models}

A test was carried out using the Fixed-Effects Model and the Random-Effects Model. The results are displayed in Table 5 and 6 respectively.

Table 4. Fixed Effects Model.

\begin{tabular}{ccccc}
\hline Variable & Coefficient & Std. Error & t-Statistic & Prob. \\
\hline NPL & & & & \\
LLP & -0.521057 & 0.136653 & -3.812987 & 0.0004 \\
CAR & -0.025099 & 0.230383 & -0.108946 & 0.9137 \\
SIZE & 0.527184 & 0.197419 & 2.670376 & 0.0105 \\
C & 0.760258 & 0.334332 & 2.273963 & 0.0278 \\
\hline
\end{tabular}

Source: Computed by researchers from annual reports of listed Banks (2007-2016)

Table 5. Random-Effects Model.

\begin{tabular}{ccccc}
\hline Variable & Coefficient & Std. Error & t-Statistic & Prob. \\
\hline NPL & & & & \\
LLP & -0.521057 & 0.107842 & -4.831675 & 0.0000 \\
CAR & -0.025099 & 0.181810 & -0.138053 & 0.8908 \\
SIZE & 0.527184 & 0.155796 & 3.383800 & 0.0015 \\
C & 0.760258 & 0.263843 & 2.881481 & 0.0060 \\
& 5.571665 & 2.090913 & 2.664705 & 0.0107 \\
\hline
\end{tabular}

Source: Computed by researchers from annual reports of listed Banks (2007-2016) 


\subsection{Correlated Random Effects- Hausman test}

Because the individual coefficients of the independent variables of both fixed and random effect models were different, the study attempted to check which model best fits the datasets. In order to determine which of the models was more appropriate to choose, correlated random effects- Hausman test was carried out. The Hausman test basically tests whether the unique errors are correlated with the regressors. Where they are correlated, preference was made for fixed effect model; otherwise random effect model would be selected. Below is the hypothesis of the Correlated Random Effects-Hausman's test:

Null hypothesis: Random effects model is appropriate.

Table 6. Results of Random Effects-Hausman Test

Test Summary Chi-Sq. Statistic Chi-Sq. d.f. Prob.

Cross-section random

31.256546

4

0.0000

The null hypothesis (Random-effects model is appropriate) is rejected since the p-value $(0.0000)$ is statistically significant and concluded that the fixed-effects model is more appropriate for this study. The appropriateness of the Fixed Effects Regression model is evidenced by the Hausman Chi-sq. statistic of 31.26 with p-value of 0.0000 . The study therefore selected the coefficients of the fixed effect model for further discussions.

Table 7- Summary of Regression Result of the Model of the Study

\begin{tabular}{cccrr}
\hline Variable & Coefficient & Std. Error & t-Statistic & Prob. \\
NPL & -0.521057 & 0.136653 & -3.812987 & 0.0004 \\
LLP & -0.025099 & 0.230383 & -0.108946 & 0.9137 \\
CAR & 0.527184 & 0.197419 & 2.670376 & 0.0105 \\
SIZE & 0.760258 & 0.334332 & 2.273963 & 0.0278 \\
C & 5.571665 & 2.649527 & 2.102891 & 0.0411 \\
R-Squared & 0.434992 & & \\
Adjusted R-Squared & 0.384769 & & & \\
Prob(F-statistic) & 0.000028 & F-statistic (8.661217) & & \\
\hline
\end{tabular}

Source: Computed by researchers from annual reports of listed Banks (2007-2016)

\subsection{Discussion of Results}

4.5.1 Non-Performing Loans (NPL)

The results in Table 7 revealed that NPL has a statistically significant negative impact on ROA at a p-value of $(0.0004)$ and coefficient value of $(-0.521057)$. This means when NPL decreases, return on asset of Ghanaian commercial banks listed on GSE also increases and vice- versa. From the results displayed in Table 7, 1\% increase in non-performing loans (NPL) reduces return on asset (ROA) by $0.5211 \%$. This means that the higher the value of NPL, the lower the profitability of these listed commercial banks in Ghana. It is therefore prudent for listed commercial banks in Ghana to manage their credit risk portfolio in order to reduce their non-performing loans and increase their profitability. This is in support of earlier studies conducted by Li and Zou (2014), Bhattarai (2014), and Kaaya and Pastory (2013) who found negative relationship between NPL and financial performance of banks. However, it is contrary to that of Alshatti (2015) and Afriyie and Akotey (2012) who found positive influence of NPL on bank profitability.

\subsubsection{Loan Loss Provision (LLP)}

Loan loss provision with p-value $(0.9137)$ and coefficient value of -0.0251 portray a statistically insignificant negative relationship with ROA. The results indicate that $1 \%$ increase in loan loss provision would reduce ROA by $0.0251 \%$. The insignificant negative relationship between loan loss provision and financial performance of listed commercial banks in Ghana indicates that listed banks in Ghana could increase profitability if they manage their loan loss provision. This will reduce the rate of non-performing loans and as a result increase their profitability.

\subsubsection{Capital Adequacy Ratio (CAR)}

Capital adequacy ratio determines the capacity of banks to meet possible losses. It can be considered as the shock absorbers in the banking operations. Banks with strong CAR tends to absorb possible loan losses, thus preventing them from failing or becoming insolvent. It shows the bank's financial strength in utilizing its capital and assets. The results of the study as shown in Table 7, revealed a positive significant relationship between capital adequacy ratio (CAR) and profitability (ROA) at a p-value of (0.0105) and coefficient value of $(0.527184)$. This indicates that when CAR increases by $1 \%$, ROA will also increase by $0.5272 \%$. The positive relationship between CAR and bank profitability is consistent with the findings of Afriyie and Akotey (2012); Bhattarai (2014); Kurawa and 
Garba (2014); and Ogboi and Unuafe (2013). However, this contradicts with the findings of Alshatti (2015); Poudel (2012); and Zou and Li (2014) who found negative linkage between CAR and bank profitability.

\subsubsection{Bank Size (SIZE)}

Again, bank size has a positive and statistically significant relationship with ROA at a p-value of 0.0278 . The results show that $1 \%$ increase in bank size will increase return on asset by 0.7603 . This means that bank size affects the financial performance of commercial banks in Ghana. As a result, Ghanaian banking sector should seek to increase their size to become active in the market, come out with a greater variety of products so as to diversify risks and achieve higher return on asset.

The Adjusted R-square shows how well the regression model fits the data. The higher the value, the closer the estimated regression fits the data. From the results in Table 8 , it shows that $38 \%$ of the variation in ROA can uniquely or jointly be explained by the four explanatory variables (NPL, LLP, CAR, and SIZE). The remaining $62 \%$ can be explained by other factors that are not in the model. The F-statistic (8.66) at p-value of 0.0000 explains the overall significance of the model. Therefore, there is a significant relationship between the dependent variable (ROA) and all the other explanatory variables.

\section{Conclusion, Recommendations and Further Research Areas}

The main objective of this study was to find the effect of credit risk management on the performance of commercial banks listed on the Ghana Stock Exchange. The study covered a period of 10 years (2007-2016) and employed panel data regression models to estimate the observed relationships. The specific objectives were to find the effect of non-performing loans, loan loss provision, capital adequacy ratio, and bank size on the financial performance of the banks. The independent variables of the study were non-performing loans, loan loss provision, capital adequacy ratio, and bank size while the dependent variable was return on asset.

Based on the test conducted this study found a significant relationship between the credit risk management variables (NPL, CAR and SIZE) and the profitability of listed commercial banks in Ghana. This findings indicate that credit risk management has a significant influence on banks' financial performance in Ghana. It is recommended for banks in Ghana to emphasize more on credit risk management. In general, banks need to maintain an optimum level of CAR as per regulatory requirement so that they will not have difficulty in meeting their financial obligations in their operations, be able to protect their depositors' investments thus promoting the stability of the financial system. The study further recommends for banks in Ghana to control and monitor NPL, and keep the level of NPL as low as possible by emphasizing more on the ability of customers to pay back before credit approvals are given, a practice that will enable banks to achieve higher performance. Finally, it is recommended for the banking sector in Ghana to increase their size to become active in the market, come out with a greater variety of products so as to diversify risks and achieve higher return on asset.

There was a limitation on the number of independent variables used in this study as only four (4) variables were considered. Future researchers should use more independent variables to the regression model in order to develop concrete literature in this study area. It is also recommended that future research should consider two dependent variables for study. The study was also limited to a period of ten (10) years due to time factor and unavailability of data for a longer period. Future research should therefore consider longer study periods (say 15 to 20 years) for the generalization of results in order to bring out the true picture of the effect of the independent variables on the dependent variable of the study.

\section{References}

Aboagye, A. Q. \& Otieku, J. (2010). Are Ghanaian MFIs' Performance Associated with Corporate Governance? Corporate Governance, Vol. 10 Issue 3, pp. 307 - 320.

Afriyie, H. O., \& Akotey, J. O (2012): credit risk management and profitability of selected rural and community banks in Ghana. Catholic University College of Ghana.

Ahmed, A. S., Takeda, C., \& Shawn, T. (1998). Bank loan loss provision: A re-examination of capital management and signaling effects (pp. 1-37). Working Paper, Department of Accounting, Syracuse University.

Alshatti, A. S. (2015). The effect of credit risk management on financial performance of the Jordanian commercial banks. Investment Management and Financial Innovations, 12(1), 338-345.

Athanasoglou, P. P., Brissimis, S. N., \& Delis, M. D. (2008). Bank-specific, industry-specific and macroeconomic determinants of bank profitability. Journal of international financial Markets, Institutions and Money, 18(2), 121-136.

Basel (2010) "Principles of management of credit risk" Consultative paper issued by the Basel

Committee on banking supervision, Basel (April 2010).

Bessis, J. (2010). Risk Management in Banking, Wiley, Third edition.

Bhattarai, Y. R. (2016). Effect of Credit Risk on the Performance of Nepalese Commercial Banks. NRB Economic Review, Tribhuvan University.

Boahene S. H, Dasah J. \& Agyei S. K. (2012). Credit Risk and Profitability of Selected Banks in Ghana. Research 
Journal of Finance and Accounting; 3(7).

Choudhry, J. K. (2011). Credit Risk Management of Loan Portfolios by Indian Banks.

(E. Murthy, Ed.) The IUP Journal of Bank Management, Vol. (2), 42-46.

Dermirgunes, K., \& Samiloglu, F. (2008). The Effect of Working Capital Management on firm profitability: Evidence from Turkey. The International Journal of Applied Economics and Finance, 2(1), 44-50.

Dong, H. P., \& Su, J.T. (2010). The Relationship between Working Capital Management and Profitability: A Vietnam Case. International Research Journal of Finance and Economics, vol.49, pp.62-71, 2010.

Epure, M., \& Lafuente, E. (2015). Monitoring bank performance in the presence of risk. Journal of Productivity Analysis, 44(3), 265-281.

Annor, E.S, \& Obeng, F.S ((2017). Impact of Credit Risk Management on the Profitability of Selected Commercial Banks Listed on the Ghana Stock Exchange. Journal of Economics, Management and Trade, 20(2): 1-10, 2017.

Francis, M. E. (2013). Determinants of Commercial Bank Profitability in Sub-Saharan Africa. International Journal of Economics and Finance, 5(9), 134-140

Giesecke, K. (2004). Credit risk modeling and valuation: An introduction. Available at SSRN 479323

Gizaw, M., Kebede, M. \& Selvara, S. (2013). The impact of credit risk on profitability performance of commercial banks in Ethiopia. African Journal of Business Management, 9(2):59-66.

Hosna, A., Manzura, B. \& Juanjuan, S. (2009). Credit risk management and profitability in commercial banks in Sweden, Master Theses.

Juliana S.I (2017). The Impact of Credit Risk on the Financial Performance of Chinese Banks. Journal of International Business Research and Marketing; 2(3): 46-52.

International Monetary Fund. (2019). Financial Soundness Indicators Compilation Guide. Prepublication Draft, https://www.imf.org > Files > Data > fsicg2019-prepublication-final-042519.

Kaaya, I. \& Pastory, D. (2013). Credit Risk and Commercial Banks performance in Tanzania: a Panel Data Analysis. Research Journal of Finance and Accounting, 4(16), pp.455 -62.

Kargi, H. S. (2011). Credit risk and the performance of Nigerian banks (Department of accounting, Faculty of Administration, Ahmadu Bello University, Zaria).

Kauko, K. (2012). External deficits and non-performing loans in the recent financial crisis. Economics Letters, 115(2), 196-199.

Kurawa, J.M \& Garba, S (2014). An Evaluation of the Effect of Credit Risk Management on the Profitability of Nigerian Banks. Journal of Modern Accounting and Auditing, ISSN 1548-6583.

Li, F., \& Zou, Y. (2014). The Impact of Credit Risk Management on Profitability of Commercial Banks. Umeå School of Business and Economics

Ogboi, C. \&Unuafe, O.K. (2013). Impact of Credit Risk Management and Capital Adequacy on the Financial Performance of Commercial Banks in Nigeria. Journal of Emerging Issues in Economics, Finance and Banking, 2 (3), pp. 703-717.

Padachi, K. (2006). Trends in working capital management and its impact on firm's performance: An analysis of Mauritan Small Manufacturing firms. International Review of Business Research Papers, 2(2), 45-46.

Pandey, I. M. (2008). Financial Management. Vikas Publishing House (PVT) Ltd, New Delhi

Perera, S., Skully, M., \& Chaudhry, Z. (2013). Determinants of Commercial Bank Profitability: South Asian Evidence. Asian Journal of Finance \& Accounting, 5(1), 365-380.

Poudel, R. P. S. (2012). The impact of credit risk management on financial performance of commercial banks in Nepal. International Journal of Arts and Commerce, 1(5), 9-15.

Raheman, A., \& Nazr, M. (2007). Working Capital Management and Profitability - Case of Pakistan Firms. International Review of Business Research Papers, 3 (1), 279 - 300

Serwadda, I. (2018). Impact of Credit Risk Management Systems on the Financial Performance of Commercial Banks in Uganda. Acta Universitatis Agriculturae et Silviculturae Mendelianae Brunensis, 66(6): 1627 - 1635.

Sharma, A. K. and Kumar, S. (2011). Effect of Working Capital Management on Firm Profitability: Empirical evidence from India. Global Business Review, 12(1), 159-173.

Tetteh, F.L. (2012). Evaluation of credit risk management practices in Ghana commercial bank limited, Master Theses, Kwame Nkrumah University of Science and Technology. 